\title{
Spectacles: Sight and Education
}

\section{Carmen M Cusack*}

Nova Southeastern University, USA

Submission: April 30, 2018; Published: May 30, 2018

*Corresponding author: Carmen M Cusack, Dept. of Justice and Human Services, Nova Southeastern University, 3301 College Ave. Fort Lauderdale, Florida 33314-7796 USA, Tel: +1-800-541-6682; Email: CC1948@nova.edu

\section{Introduction}

Sight is a basic requirement in many learning environments. Glasses may symbolize intellect; but, may attest to envy and destruction of intelligentsia. Society and culture attempt to criticize subtle and overt annihilative processes through art and other media [1]. Yet, even direct confrontation (e.g., anti-bullying campaigning) has had little effect on vicious resentment of sight and education.

Glasses are tools. Children, who wear glasses, may have an advantage. Some individuals may be deprived or deprive themselves of corrective lenses, including contact lenses, to avoid appearing to possess education. Pearl Jam's 1994 music video "Jeremy" depicts a student, who has trouble seeing the chalkboard [2]. He wants to wear glasses, but as a result of his family's violence, they castigate his career prospects by denying him sight, and consequently, education [3]. Because he cannot see the chalkboard, he gives an incorrect answer in class [4]. Mental illness (e.g., anxiety) causes him to perpetrate gun violence at school [5].

Trauma, heredity, and environment are some factors neglected or unrecorded by doctors when persons refuse or are deprived of corrective lenses. Professional processes may be compromised when individuals are pressured to hide impairment. For example, an analysis of nonconsensual insemination may require a professional to know whether a perpetrator or victim was visually impaired.

Education is necessary to provide treatment. Relationships between sight and education have been discussed by the U.S. Supreme Court. In Williamson v. Lee Optical [6], an optician attempted to disregard doctors' education. The optician took his argument to the Supreme Court where education requirements were upheld.

Rational review was articulated in this case. Rational review is an analytical framework used to decide whether a law is Constitutional in cases that do not raise questions about the First Amendment, substantive due process, or equal protection. It is the lowest standard of scrutiny and applies in most cases. The challenged law prohibited opticians from "fitting or duplicating lenses without a prescription from an ophthalmologist or optometrist." [7]. The Court unanimously held that laws are Constitutional as long as they are reasonably related to a rational government interest.

The Court may have helped to protect educated professionals by including "good, hard dicta" [8]. "The Oklahoma law may exact a" professional standard; and thus, "it is for the legislature, not the courts, to balance the advantages and disadvantages of" such a "requirement" because "it might be...a rational way to correct" issues [9]. The law was a rational requirement made by the legislature to protect people requiring corrective lenses and to legislate the significance of education. "An eyeglass frame, considered in isolation, is only a piece of merchandise [;b]ut an eyeglass frame is not used in isolation....[I]t is used with lenses." [10] The Court's dicta was "an attempt to free the profession." [11].

In an era when education is associated with violence, and also with problem resolution, implications for sight are sweeping. For example, animals such as white tigers in zoos and deer on protected land, may benefit from additional attention to sight. Those, who continue to value relationships between sight and education, may invite and inspire those, who may have challenged education and sight, instead healthily to participate.

\section{References}

1. Leonardo Di Caprio, The Great GatsBy (2013) David Cross, Dr. Tobias Funke, February 20, 2012. Available at https://www.youtube.com/ watch?v=Ddt9CHJj9sw. Slayer, "Eyes of The Insane" (2006). Available at https://www.youtube.com/watch?v=FhwRunMCNAo

2. Pearl Jam, "Jeremy," Ten (1994) Available at https://www.youtube. com/watch?v=MS91knuzoOA. Compare, Nova Southeastern University. Distance Education. Available at www.nova.edu/academics/distanceeducation.html

3. "Jeremy" (1994) Tori Spelling, SAVEd BY the Bell, October 6, 1990. Available at https://www.youtube.com/watch?v=pP5_UOdqC2g. Puff Daddy\& the Family, "It's All about the Benjamins" (Remix I) No WAY OUT (1997) Available at https://www.youtube.com/ watch?v=PaEMpAlppNE).

4. "Jeremy" (1994) Out Kast, "Rosa Parks," Aquemini (1998) Available at https://www.youtube.com/watch?v=drsQLEU0N1Y. Plessy v. Ferguson, 163 US 537 (1896). Brown v. Board of Education of Topeka, 347 U.S. 483 (1954). Boynton v. Virginia, 364 U.S. 454 (1960).

5. “Jeremy” (1994) Virginia v. Black, 538 U.S. 343 (2003). 
6. Williamson v. Lee Optical, 348 U.S. 483 (1955)

7. Lee Optical, 348 U.S. $483,486$.

8. Elizabeth Price Foley, Florida International University College of Law, Miami, Florida(October,2006).
9. Id. at 487-488.

10. Id. at 490 .

11. Id. at 491. See, Semler v. Dental Examiners, 294 U.S. 608 (1935).

\section{Your next submission with Juniper Publishers} will reach you the below assets

- Quality Editorial service

- Swift Peer Review

- Reprints availability

- E-prints Service

- Manuscript Podcast for convenient understanding

- Global attainment for your research

- Manuscript accessibility in different formats

( Pdf, E-pub, Full Text, Audio)

- Unceasing customer service

Track the below URL for one-step submission https://juniperpublishers.com/online-submission.php 